\title{
Indicators Benchmarking of Cement-Based Construction Technologies: Brazilian Case Study
}

\author{
Alberto Casado Lordsleem Júnior, Bárbara Eloá Gonçalves de Lima \\ Department of Civil Engineering, Polytechnic School of Pernambuco University, Recife, Brazil \\ Email: acasado@poli.br
}

Received 24 September 2014; revised 15 October 2014; accepted 1 November 2014

Copyright (C) 2014 by authors and Scientific Research Publishing Inc.

This work is licensed under the Creative Commons Attribution International License (CC BY). http://creativecommons.org/licenses/by/4.0/

c) (7) Open Access

\section{Abstract}

The adoption of performance indicators promotes knowledge of quantitative and qualitative material wastes in businesses and, when inserted in a collaborative process, provides a comparative evaluation of results between companies and, thereafter, an identification of best practices (benchmarking). The purpose of this paper is to present the best practices identified by performance indicators, related to the measurement of wastes and associated to construction companies participation in the benchmarking research process "Implementation of a system of performance indicators of cement-based construction technologies of the Community of Construction of Recife city in Brazil-PROGRIDE", coordinated by the Brazilian Association of Portland Cement-ABCP. Therefore, it was sought to characterize best practices that led to the benchmarking of performance indicators related to the wastes of concrete, industrialized mortar for masonry settling and blocks/ bricks. As a contribution, a set of factors that characterize the best practices for each technology and conducted to benchmarking were identified.

\section{Keywords}

Indicators, Concrete, Masonry, Construction, Technologies

\section{Introduction}

The Brazilian construction industry has experienced a moment of elevated growth and the existing competitiveness confirms the need for changes, according to Pinho [1], since it has generated concerns such as: meeting the deadlines for the delivery of constructions and the inability to fulfill the costs in the determined budget. In order to execute more agile services to have a better cost efficiency, adjustments are necessary so that the building 
materials are used more efficiently.

Still, construction companies have to live with the criticism of belonging to a sector wasteful of resources [2]. In particular, the waste of materials at construction sites is something always discussed in the technical scope, demonstrating the need for frequent changes and to seek new perspectives to improve the production process of construction works.

Aiming to better manage the production process and reduce the waste of materials, construction companies have adhered to the performance measurement through indicators. Since this is a relatively recent practice, it has received impulse through the implementation and certification of quality management systems in construction companies [3].

The adoption of performance indicators promotes knowledge of corporate performance and when inserted in a collaborative process, it offers a comparative evaluation of results between construction companies and identification of the best practices [4].

Benchmarking is the name given to comparative evaluation for the search for the best practices in the industry that lead to superior performance. It is seen as a positive and proactive process through which the company examines how the other one performs a function in order to improve the same or a similar function [5].

Within this context, the importance of monitoring performance indicators within the construction site was registered, as a tool for monitoring production processes and thus, serves as a tool for continuous improvement.

This research aimed to identify the best practices verified by the performance indicators associated with the cement-based construction technologies from construction companies participating in a benchmarking experience. The reference was the program conducted with the participation of twelve construction companies located in the city of Recife, in Brazil, participants in the process of benchmarking of the research "Implementation of a system of performance indicators of cement-based construction technologies of the Community of Construction in Recife city in Brazil-PROGRIDE” coordinated by the Brazilian Association of Portland Cement$\mathrm{ABCP}$ and conducted by the POLITECH research group of the Polytechnic School of Pernambuco University. Therefore, three operational elements (spreadsheets) were developed to conduct the research to characterize the factors that culminated in acquiring the benchmarking of performance indicators, namely: waste of concrete, waste of industrialized mortar for masonry settlement and waste of blocks/bricks. It was aimed to identify the practices that led companies that presented the best results to overcome in a specific indicator.

The factors identified in the research for each indicator will be presented and discussed as follows, since the methodology until the conception of the company's practices that obtained the benchmarking.

\section{Methodology}

The research consisted of a descriptive research, whose purpose includes literature review and case study. The descriptive facts are observed, recorded, analyzed and interpreted, without interference from the researchers. Standardized techniques for collecting data from operational element (spreadsheets questionnaires) and systematic observation were used.

The research was developed in the course of a year and was divided into four stages.

Stage 01: Definition of potential features relevant to obtain performance benchmarking. Accomplishment of literature review regarding the subject (standards, thesis and papers), as well as the study of PROGRIDE.

Stage 02: Development of the operational element under the form of spreadsheets and definition of participant companies in research.

Stage 03: Field research with the investigation of relevant factors and follow-up through the operational element.

Stage 04: Identification of relevant features and characterization of best practices with its detailed description, with the purpose of organizational improvement, providing competitive superiority.

The implantation of PROGRIDE contemplated three collection cycles, where construction companies involved in the program were able to collect monthly data on indicators of waste of materials and labor productivity of reinforced concrete structure, the elevation of the sealing masonry and plaster coating of the facade. Over 150 results were obtained, originated from 15 sites of 12 construction companies.

At this stage of the research, knowledge and definition of potential factors relevant for a company to reach benchmarking were sought. Initially, benchmarkings from PROGRIDE were identified regarding three analyzed indicators: waste of concrete, waste of industrialized settling mortar and waste of blocks/bricks. 


\subsection{Waste of Concrete}

Reinforced concrete can be defined as "the union of plain concrete and a material resistant to traction (involved by concrete) so that both jointly resist the soliciting forces”. The elements of the superstructure of reinforced concrete, responsible for resisting these efforts, are basically pillars, slabs and beams. For the production of these elements, services related to molds, assembly and concreting are performed [6].

Some factors can be considered as potential influencers in the waste of concrete, with the possibility of being present both in the preparation of the site to be concreted as well as in the place of the concrete application. The waste of concrete can be influenced mainly by solicitation planning of concrete according to what was originally designed; quantitative control during its delivery; awareness in choosing the transport equipment, in the event of a pump, predict the use of remaining concrete in the pipe and in the pump; geometric control of the structural elements before and during concreting, and the use of good quality molds [1] [7] [8].

\subsection{Waste of Mortar for Settling}

The mortar for masonry laying is used for the elevation of walls of bricks or blocks. Its main functions are to unite the masonry units in order to form a monolithic element, contributing to the resistance to lateral forces and distribute the loads acting on the wall evenly throughout the resistant area of the blocks.

Waste of mortar for laying, according to Tcpo [8], is mainly influenced by the use of rational tools and equipment for the settlement or transportation of mortar, the adoption of materials/components of good quality and use of the specific design for masonry.

The Tcpo-Table of Composition of Prices for Budgets corresponds to the largest credible database in the Brazilian Civil Construction Industry. Its functionality consists in guiding and referencing the elaboration of budgets of construction and civil works.

Construction companies can gain efficiency in the use of industrialized mortar, performing an analysis on the processes involved, which range from receiving to the application of the material [9].

\subsection{Waste of Blocks/Bricks}

The blocks or bricks are components used in the construction of sealing masonry, which bonded by mortar joints, form a rigid union that provides division of internal environments and peripheric coverage of a building [10].

The Tсро [8] reports as influential factors in the waste of blocks/bricks, the use of complementary components for modulation accuracy, the use of tools and rational equipment for the execution of cuts the adoption of good quality materials, the use of pallets for the supply of blocks/bricks and specific utilization for the design of masonry.

\section{Development of the Operational Element}

Before you begin to format your paper, first write and save the content as a separate text file. Keep your text and graphic files separate until after the text has been formatted and styled. Do not use hard tabs, and limit use of hard returns to only one return at the end of a paragraph. Do not add any kind of pagination anywhere in the paper. Do not number text heads - the template will do that for you.

Finally, complete content and organizational editing before formatting. Please take note of the following items when proofreading spelling and grammar:

For the development of the research and determination of the companies participating in the process of analysis of performance indicators, it was sought to determine between twelve participating companies in the benchmarking process developed by PROGRIDE, those who had the best results.

It is noteworthy that the description of the implementation of PROGRIDE is contemplated in the Master's Degree Dissertation by Pinho [1], whose development will not be treated in this work, except when essential to the understanding of this research.

The responsibility of data collection in PROGRIDE was of the construction companies, which were properly trained for the application of standard methodology in their respective worksites. After the monthly period of collection, the companies forwarded the results to the researchers involved in order to obtain reference values of the benchmarking process. From these values, it was possible to determine the companies that have excelled in the indicators mentioned, and thus seek to identify the practices adopted that resulted in the benchmarkings. 
For the identification of the practices adopted, from the reading of the bibliographies (some mentioned previously), benchmark spreadsheets of three indicators that are the aim of the research were prepared: waste of concrete, waste of industrialized mortar for settlement and waste of blocks/bricks and they will be presented with the checklist completed by the construction companies (Tables 4-6 respectively). The worksheets were developed in the format of checklists, allowing the identification of practices adopted, applied through visits and interviews onsite with those responsible for the companies that generated the benchmarkings.

\section{Results and Discussion}

\subsection{Characterization of Construction Companies and Worksites}

For the analysis of the results over the 3 collection cycles of PROGRIDE, characterizations of worksites and companies participating in this study were performed. These characterizations were important for detailment and analysis of benchmarking (Table 1).

From Table 1, some features of the worksites were verified, such as: supervision staff, ranging from 03 to 06 members; forecast of the duration of the work, varying from 27 to 59 months; number of slabs of the enterprise, ranging from 08 to 22 slabs. Some characteristics are common to the three analyzed, as the type of design, being all residential.

The characterization of the companies participating in the program is presented in Table 2.

All participating companies in the program develop activities related to the construction of residential buildings, in addition to performing residential construction, all companies have participated in some type of institutional training program for quality.

Initially, the values were identified through PROGRIDE benchmarking, which also allowed to identify the companies that reached benchmarking in Table 3 .

The results presented in Table 3 were collected and managed by PROGRIDE. They represented the best values obtained, being analyzed then, by indicator, in order to identify the conditions that led a determined company to obtain certain results.

\section{Table 1. Characterization of worksites.}

\begin{tabular}{lccc}
\hline & Worksite A & Worksite B & Worksite C \\
\hline 1) Staff (supervision) & & & \\
Interns/Foreman/Workers & $01 / 01 /-$ & $04 / 01 / 05$ & $01 / 01 /-$ \\
Engineers & 01 & 01 & Residential \\
2) Types of companies & Residential & Residential & Medium \\
3) Pattern of companies & Popular & High & Pattern \\
4) Type of design & Singular & Singular & 50 months \\
5) Forecast of work duration & 27 months & 49 months & 22 \\
6) Technical data & & 32 & 60.00 \\
Number of slabs & 08 & 97.00 & 2.71 \\
Total height of the building (m) & 29.40 & 2.95 & Single mass and ceramic \\
Floor height (m) & 3.00 & & Reticulated with solid slab \\
7) Typologies & & and edge beams \\
Structure & Reticulated with ribbed slab and edge beams & Ceramic \\
Sealing (block) & Concrete & Ceramic & Ceramic \\
Internal coating & Mortar/Texture & & \\
External coating & Plaster, painting and ceramic & \\
\hline
\end{tabular}


Table 2. Characterization of construction companies.

\begin{tabular}{|c|c|c|c|}
\hline & \multicolumn{3}{|c|}{ Construction companies } \\
\hline & A & $\mathrm{B}$ & $\mathrm{C}$ \\
\hline 1) Constructed area in the last 5 years $\left(\mathrm{m}^{2}\right)$ & 45.000 & 196.189 & 5247 \\
\hline \multicolumn{4}{|l|}{ 2) Activities performed by the company in the last 2 years } \\
\hline Incorporation and construction of residential edifications & $\mathrm{X}$ & $\mathrm{X}$ & \\
\hline Residential worksites for private clients & & & $\mathrm{X}$ \\
\hline Industrial worksites for private clients & $\mathrm{X}$ & & \\
\hline Commercial worksites for private clients & & $\mathrm{X}$ & \\
\hline Public worksites (social interest housing) & & $\mathrm{X}$ & \\
\hline \multicolumn{4}{|l|}{ 3) Participation in an institutional program (training) } \\
\hline Agreement with the university & $\mathrm{X}$ & & \\
\hline Consulting company & $\mathrm{X}$ & $\mathrm{X}$ & $\mathrm{X}$ \\
\hline SENAI & & & $\mathrm{X}$ \\
\hline SEBRAE & & $\mathrm{X}$ & \\
\hline SINDUSCON & $\mathrm{X}$ & $\mathrm{X}$ & $\mathrm{X}$ \\
\hline \multicolumn{4}{|l|}{ 4) Designs of improvement already developed } \\
\hline Literacy & $\mathrm{X}$ & $\mathrm{X}$ & $\mathrm{X}$ \\
\hline ISO 9001/Standardization in processes & $\mathrm{X} / \mathrm{X}$ & $\mathrm{X} / \mathrm{X}$ & $\mathrm{X} / \mathrm{X}$ \\
\hline Safety at work & $\mathrm{X}$ & $\mathrm{X}$ & $\mathrm{X}$ \\
\hline
\end{tabular}

Table 3. Benchmarking of construction companies.

\begin{tabular}{|c|c|c|c|c|c|}
\hline Indicators & Benchmarking & Company & Site & Median $^{*}$ & Maximum $^{*}$ \\
\hline \multicolumn{6}{|c|}{ Concreting-pillar } \\
\hline Waste of concrete (\%) & 5.18 & A & A & 6.66 & 17.29 \\
\hline \multicolumn{6}{|c|}{ Concreting-Beam + slab + pillar complement } \\
\hline Waste of concrete (\%) & 2.00 & A & A & 4.75 & 26.61 \\
\hline \multicolumn{6}{|c|}{ Sealing masonry } \\
\hline Waste of blocks/bricks (\%) & 0.83 & B & B & 3.50 & 15.00 \\
\hline Waste of mortar (\%) & $12.34^{* *}$ & $\mathrm{C}$ & $\mathrm{C}$ & 114.13 & $429.29^{* * *}$ \\
\hline
\end{tabular}

*Regarding the group of participating companies from PROGRIDE; ${ }^{* *}$ Reference consumption adopted $=20.0 \mathrm{~kg} / \mathrm{m}^{2} ;{ }^{* * *}$ Reference consumption adopted $=$ $6.6 \mathrm{~kg} / \mathrm{m}^{2}$.

\subsection{Influential Factors of Benchmarking}

\subsubsection{Regarding Concrete Waste}

Worksite A reached benchmarking in concrete pillar waste of 5.18\% and of concrete beam + slab + pillar complement of $2.00 \%$.

The interview was held with the engineer responsible for Worksite A and in it was completed the checklist shown in Table 4. The questionnaire was assembled as follows: The factors that may have led the company to achieve benchmarking were presented, being analyzed their existence and frequency at the worksite, besides other factors verified during the interview/visit.

In Worksite A, it was not possible to measure the amount of concrete in the trucks as there was no way to confirm whether the volume of concrete that was provided by concrete supplier was the same as that requested; so a 
Table 4. Spreadsheet for the characterization of the concrete waste indicator from Site A.

\begin{tabular}{|c|c|c|c|c|c|}
\hline \multirow{2}{*}{ Factor } & \multicolumn{5}{|c|}{ Frequency of visualization of the factor at the worksite } \\
\hline & Always & Often & Sometimes & Seldom & Never \\
\hline Accurate estimate of the volume of concrete to be used & & $\mathrm{X}$ & & & \\
\hline Equal portions to concrete & $\mathrm{X}$ & & & & \\
\hline Well-structured molds & $\mathrm{X}$ & & & & \\
\hline Existence of control in the amount of concrete received & $\mathrm{X}$ & & & & \\
\hline Big concretings & & $\mathrm{X}$ & & & \\
\hline Pump does not retain concrete & $\mathrm{X}$ & & & & \\
\hline Use of remaining concrete on the transport element & & $\mathrm{X}$ & & & \\
\hline Request of remaining concrete consistent with the progress of concreting & & $\mathrm{X}$ & & & \\
\hline Utilization of tools needed to control the level of concrete & $\mathrm{X}$ & & & & \\
\hline There is no remaining concrete in the molds & & & $\mathrm{X}$ & & \\
\hline Area of regular access & $\mathrm{X}$ & & & & \\
\hline Little vibration of concrete in transportation & $\mathrm{X}$ & & & & \\
\hline The thickness of the slab is not increased & $\mathrm{X}$ & & & & \\
\hline Height of free fall of the concrete is less than 2 meters & $\mathrm{X}$ & & & & \\
\hline Good operating of the elements of concrete transport & $\mathrm{X}$ & & & & \\
\hline Encouragement of workers to minimize wastes & & & & & $\mathrm{X}$ \\
\hline
\end{tabular}

guaranteed surplus ranging around $3 \%$ to $5 \%$ was solicited. This additional amount of concrete that was requested as prevention, in most cases, was used in other concretings.

The last truck, to prevent waste, was requested with only the amount needed for the completion of concreting. On arrival of the truck to the construction site, quality control was always performed, the slump test, avoiding future problems with the consistency of concrete. The request for remaining concrete was always according to the progress of concreting to be held.

For the control and leveling of concrete, metal grids were used, which had bolts welded in its extension, where the bolt threads are adjusted according to the height desired to be controlled. At the end of each concreting, a mapping of the areas was done, identifying where each concrete truck was applied in order to avoid future problems, in case the concrete does not reach the specified resistance.

During the work, there was great concern as to the path where the concrete transporting equipments would go through, the accesses to the construction site were prepared so the waste due to spills were not reported and wheelbarrows were always in good condition. When in slabs and pillars, concreting was performed with the spear, and what was left in the truck, was carried in barrels (maintenance performed weekly), which had access to the place of loading and unloading, and generally covered with woods to avoid waste of concrete.

The remaining concrete on the transport equipment was not wasted, thus it was used in other concretingsbeams and sidewalks. The release pumps were adjusted and were maintained so that they commonly did not retain concrete.

In the worksite of Worksite A, the slabs were equal, thus the slab adjustment was made only on the first concreting. On the others, the amount of concrete became standard, so that the volume was previously known, the request was consistent with the amount to be used, avoiding waste.

As for molds, they were very well structured so that no mold burst/opened during construction. Sometimes, there was remaining concrete in the molds, and this concrete in many times, could not be reused in other concretings, being one of the reasons for concrete waste. The thickness of the slab, in no concreting, was higher than that anticipated in the design, which could cause unnecessary waste.

The construction made no kind of incentive to employees so they could reduce wastes. Although, the engineer considered that they could be further reduced if the employees had full awareness of the importance for the total 
cost of the work as well as the damage to the environment.

\subsubsection{Regarding Waste of Settling Mortar}

In Enterprise C, which showed a benchmarking value of $12.34 \%$, the interview was held with the engineer responsible for the quality of the work and in it, the checklist shown in Table 5 was answered.

As for molds, they were all well structured so that no mold burst/opened during the construction. Sometimes, there was a remainder of concrete in the molds, this concrete for many times could not be reused in other concretings, being this one of the reasons for the waste of concrete. The thickness of the slab, in no concreting, was higher than anticipated in the design, which could cause unnecessary waste.

During the interview and visit to the construction site, were observed factors that led this design to reach the benchmarking in waste of mortar.

Depending on the volume of mortar required by the bricklayer and for the person responsible for the mixture, it was produced by a mixer, ensuring to obtain a higher workability rather than when produced manually. This way, it was perceived that the mortar was settled over the ceramic block gaining more adherence.

For the production of mortar in the mixer, water measuring instruments such as graded buckets were used to ensure that the mortar contained the water quantity indicated by the manufacturer.

In order to ensure that the material could be transported in an easy and practical way, avoiding transport wastes by improper handling, the worksite was always organized, and the way the wheelbarrows would go through were prepared in advance.

There was a concern with the condition and operational quality of the transportation equipment and wheelbarrows. There was also the concern as to the preventive maintenance of hoists and lifts, respecting deadlines previously established by hiring mechanical engineers and specialized technicians.

The storage of mortar sacks was performed properly to avoid the action of humidity over the material. For such, the mortar was stored on pallets (Figure 1) and it was aimed to ensure that the warehouse was always ventilated.

The stock keeper controlled the departure of materials with spreadsheets which ensured that the amount of material that would be used was consistent with the planning. He was also responsible for making sure that the oldest sacks were used before the most recent, implying that the mortar was always used within the validity period.

At the worksite of Enterprise C, a design for the production of the masonry sealing was used, specifying the materials and conceiving the construction details such as the modulation of the blocks, causing the mortar to be

\begin{tabular}{|c|c|c|c|c|c|}
\hline \multirow{2}{*}{ Factor } & \multicolumn{5}{|c|}{ Frequency of visualization of the factor at the worksite } \\
\hline & Always & Often & Sometimes & Seldom & Never \\
\hline Accurate estimate of the volume of concrete to be used & $\mathrm{X}$ & & & & \\
\hline Use of specific design for masonry & $\mathrm{X}$ & & & & \\
\hline Good accommodation of mortar in stock, no action of humidity & $\mathrm{X}$ & & & & \\
\hline Use of older sacks before the most recent & $\mathrm{X}$ & & & & \\
\hline Mortar not unloaded on the floor & & $\mathrm{X}$ & & & \\
\hline No over-thickness of the horizontal joints of the masonry & & $\mathrm{X}$ & & & \\
\hline No over width of the vertical joints of the masonry & & $\mathrm{X}$ & & & \\
\hline Use of specific tools for settlement, such as tubes and boards & $\mathrm{X}$ & & & & \\
\hline Transport of mortar by appropriate ways and/or equipment for such & $\mathrm{X}$ & & & & \\
\hline Reutilization of mortar that falls on the floor & & $\mathrm{X}$ & & & \\
\hline It is necessary to settle until the mortar is over & $\mathrm{X}$ & & & & \\
\hline Encouragement of workers to minimize wastes & $\mathrm{X}$ & & & & \\
\hline Good operation of the transport elements mortar & $\mathrm{X}$ & & & & \\
\hline
\end{tabular}


improperly used to fill voids left by the absence of specific block for modulation (fillings increase the consumption of mortar). With the design, the electrical installations were designed to avoid rework and break of blocks that would leave spaces and would be filled with mortar.

The volume of mortar going up to the apartments was always compatible with the amount of blocks that would be settled at that moment, secured by the design for the production of masonry. According to specifications, the vertical and horizontal joints did not exceed one (01) centimeters $(\mathrm{cm})$, avoiding unnecessary use of mortar (Figure 2).

The use of specific tools for settling the mortar on the block, such as the trowel is used in the worksite of construction C, and of great importance to minimize wastes. With the trowel, the mortar is spread on the walls of the blocks with horizontal and vertical movements, using only the recommended amount of mortar.

Constantly, bricklayers and helpers received training, ministered both by more experienced employees of the company, as well as engineers and technicians or by institutions and organizations, in order to improve productivity and settlement services. For the employees, it was recommended that they used instantly the mortar that fell on the floor, which remained invariably clean. Moreover, employees were given incentives to minimize the waste of mortar. They functioned so that the amount of mortar that was not wasted, was reversed in financial bonuses to the employees, considering the consumption and the goal set by the company.

Monthly, monitoring was carried out to evaluate wastes and productivity, and the results were presented in tables at the construction site, so that employees could compare and evaluate the progress of the work in respect to quality.

\subsubsection{Regarding the Waste of Blocks/Bricks}

Construction company B had the best result with the indicator of block/brick waste with a total of $0.83 \%$. Table 6 presents the results of the responses of the checklist.

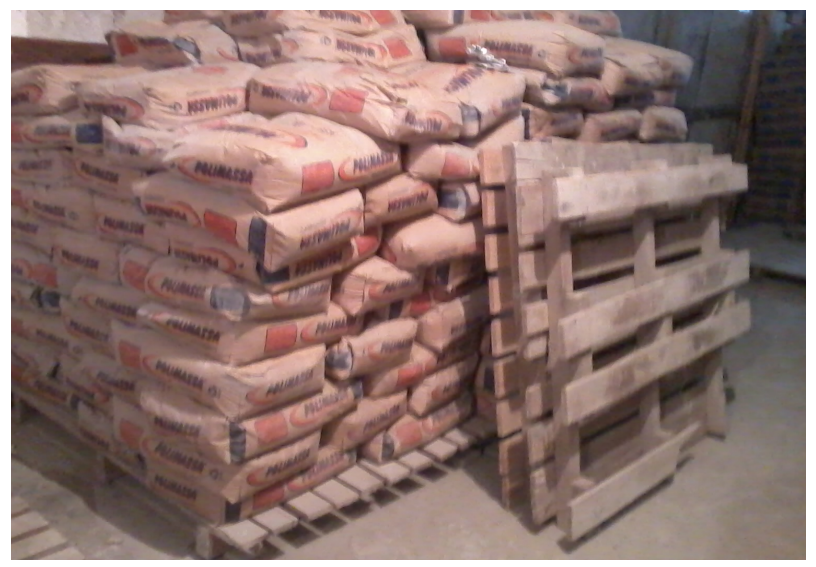

Figure 1. Mortar stocked on pallets.

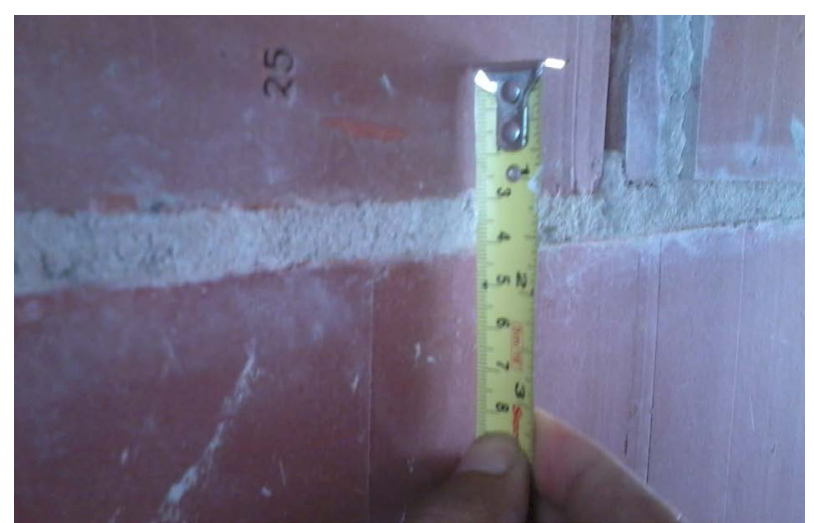

Figure 2. Joints within specifications. 
Analyzing Table 6, it is also possible to observe which practices adopted by construction company B minimized waste of materials. Construction company B, due to a greater control of wastes, developed a program called "Work in hand", and in this program each bricklayer that was responsible for laying the blocks on the wall had a masonry design next to him. In the program, a system of communication between the floors where it was functioning, the inventory and labor management was developed. Communication was performed using an apparatus located on each floor of the worksite, where three kinds of emitted light signals: green (the service is in progress normally), yellow (service stop risks) and red (the service is stopped) were used.

With this system, based on the Japanese philosophy of Andon and Kanban, there was greater control over the amount of blocks/bricks that were being used and whether the planned amount was consistent with what was being used. If a yellow or red light was lit on the floor in question, it meant that the site needed attention or the adequate procedures should be taken as to the quantity of blocks.

Verifying the existent specific masonry design of the worksite, kits were assembled and arrived at the pavements with the amount of blocks necessary to lay on the respective floor, this way, avoiding remaining blocks. In this worksite, modular blocks (family of blocks with its own compensators) were used, that composed the kits in quantities correspondent to the floor. Still, along with the electrical design, blocks with suitable modulation for the use in the composition of the electrical kit (electrical blocks: openings already undertaken by the manufacturer for the bolting of the electricity boxes) were used.

Moreover, construction company B invested a lot in specialized training for each function performed by the employees, so, for example, when the cut of additional blocks became necessary, it was done by a professional and with the use of tools, such as a diamond disc suitable for such, thus preventing that the block was torn or fractured during the cutting.

The blocks that arrived at the construction site went through quality control and those that were not within specifications were returned to the supplier and the company received other blocks within the quality standard.

The blocks were stored on pallets and separated and classified by type in pens, according to the modulation of the block. They were transported in pallet carts by planned access paths and cemented to prevent it from falling.

\section{Conclusion}

The growth of the construction industry has increasingly demanded the need to build in an efficient and rational way, to meet the demands of the consumer market in quality and time planned as well as the budgeted cost. The construction and management practices presented by the construction companies in the survey demonstrated to

Table 6. Spreadsheet for the block/brick waste indicator characterization from Site B.

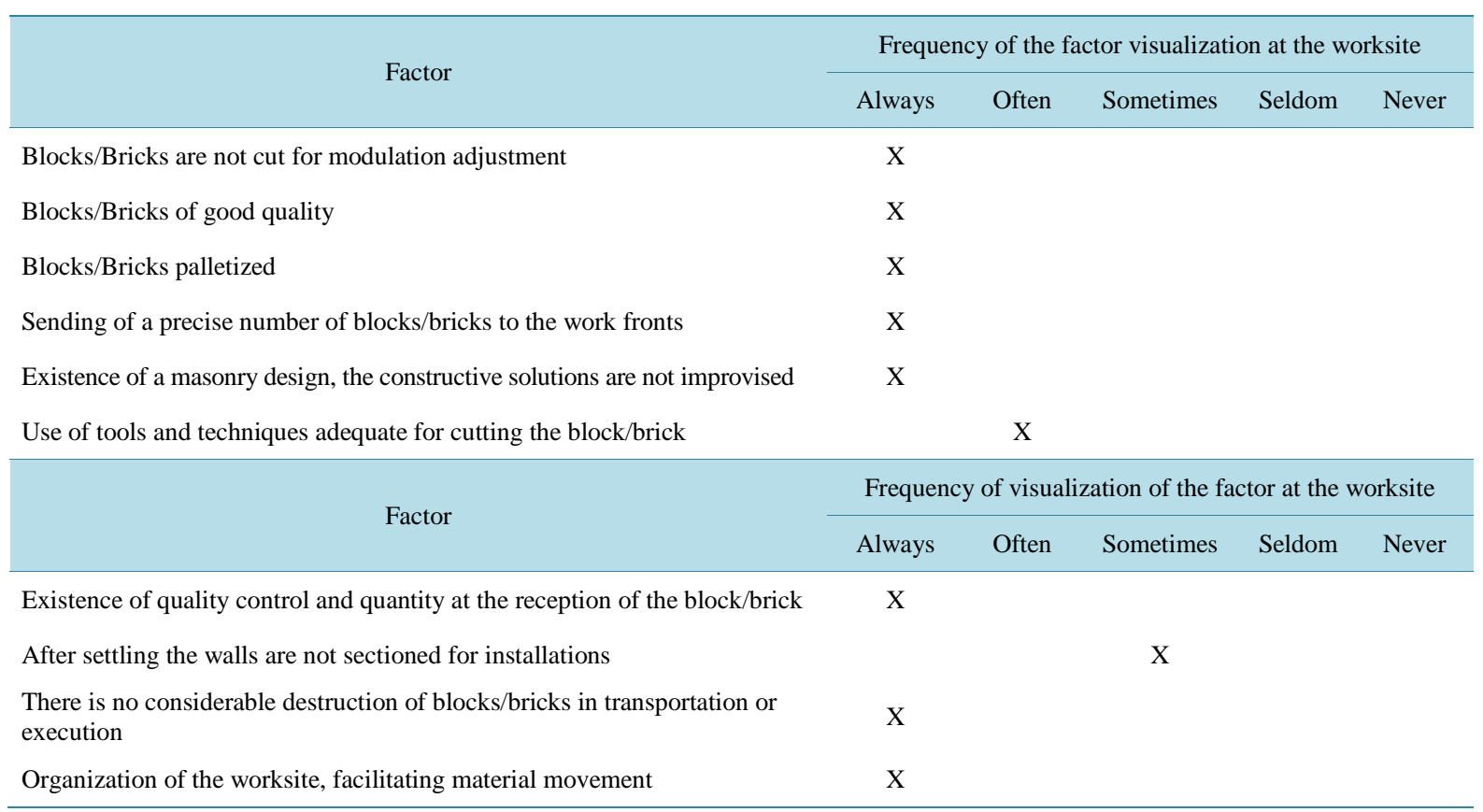


be consistent with the current context of improvement needed for the development of the construction of buildings. In the search for the rationalization of construction, it was found that it is necessary to control the work processes. Practices to be adopted must necessarily lead to waste minimization, still allowing taking steps to improve the management of materials. Thus, this research aimed to identify the best practices pointed out by the performance indicators, related to the measurement of wastes and associated to cement based constructive technologies of construction companies participating of the benchmarking process. Having the entire theoretical basis for such, operational elements which allowed characterizing the benchmarks obtained by the three companies selected from PROGRIDE were developed. The worksheets subsidized the collection of data at the construction sites and thus, it was possible to characterize and determine which of the main factors caused construction companies to obtain the best values for the indicators. From the results obtained during the research, it was possible to conclude that most of the best practices identified are associated with the design for production, construction site planning, resource management and prior definition of stock and equipment spaces.

\section{References}

[1] Pinho, S.A.C. (2013) Desenvolvimento de programa de indicadores de desempenho para tecnologias construtivas à base de cimento: Perdas, consumo e produtividade. Master Dissertation, Pernambuco University, Recife.

[2] Pinto, T.P. (1989) Perdas de materiais em processos construtivos tradicionais. Ph.D. Dissertation, Federal University of São Carlos, São Carlos.

[3] Duarte, C.M.M. (2011) Desenvolvimento de sistema de indicadores para benchmarking em empresas de construção civil. Master Dissertation, University of Pernambuco, Recife.

[4] Lordsleem Jr., A.C., Andrade, F.K.G. and Pinho, S.A.C. (2011) Benchmarking em construtoras: Caracterização das melhores práticas de 04 indicadores de execução de obras. In: VIII Encontro Tecnológico da Engenharia Civil e Arquitetura-ENTECA, Maringá, 1-12.

[5] Bakens, W., Viries, O. and Courtney, R. (2005) International Review of Benchmarking in Construction. PSIBOUW, Amsterdã.

[6] Bastos, P.S.S. (2008) Fundamentos do concreto armado. http://wwwp.feb.unesp.br/pbastos/concreto1/FUNDAMENTOS.pdf

[7] Araújo, L.O.C. (2000) Método para a previsão e controle da produtividade da mão de obra na execução de fôrmas, armação, concretagem e alvenaria. Master Dissertation, São Paulo University, São Paulo.

[8] Tcpo (2010) Tabelas de Composição de Preços para Orçamentos. Pini, São Paulo.

[9] Oliveira, F.A.L. (2006) Argamassa industrializada: Vantagens e desvantagens. Civil Engineer Degree Dissertation, Anhembi Morumbi University, São Paulo.

[10] Lordsleem Jr., A.C. (2000) Execução e inspeção de alvenaria racionalizada. Editora O Nome da Rosa, São Paulo. 
Scientific Research Publishing (SCIRP) is one of the largest Open Access journal publishers. It is currently publishing more than 200 open access, online, peer-reviewed journals covering a wide range of academic disciplines. SCIRP serves the worldwide academic communities and contributes to the progress and application of science with its publication.

Other selected journals from SCIRP are listed as below. Submit your manuscript to us via either submit@scirp.org or Online Submission Portal.
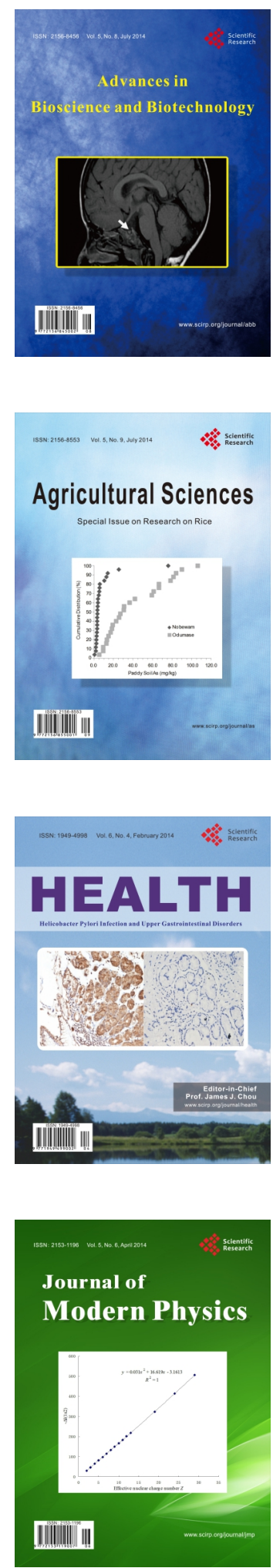
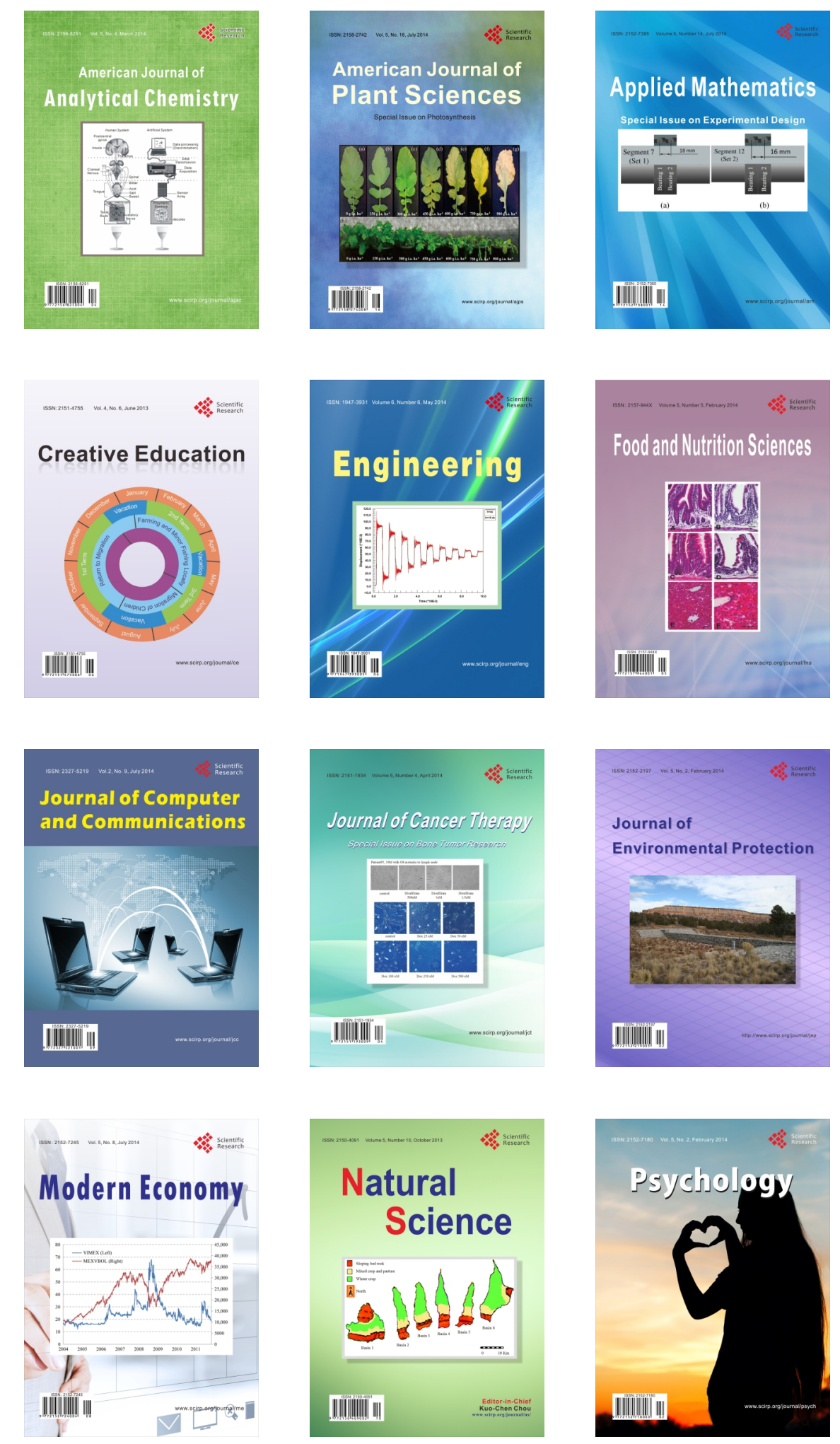